\title{
LC-Q-TOF-MS driven identification of potential degradation impurities of venetoclax, mechanistic explanation on degradation pathway and establishment of a quantitative analytical assay method
}

\author{
Dhruvisha Pokar, Amit Kumar Sahu and Pinaki Sengupta* (i)
}

\begin{abstract}
Venetoclax is a selective orally active $\mathrm{BCl}-2$ protein inhibitor very recently approved by USFDA to treat chronic lymphocytic leukemia and other hematological malignancies. Postmarketing surveillance of any drug depends on its acceptability based on risk to benefit ratio. When risk outweighs the benefits, withdrawal of an already marketed drug is warranted. Presence of impurity is the primary cause of increased risk in a drug substance or drug product. With the discovery of newer molecules, it is of great importance to establish advanced analytical techniques for quantification of the drugs as well as their related impurities to address the prospective regulatory queries even if it is already in the market. In this study, a quantitative analytical assay method has been developed and validated for quantification of venetoclax in presence of its degradation impurities. A stress study was performed to examine the stability of the drug in hydrolytic, oxidative, thermolytic and photolytic environments. Venetoclax was found to be prone to degradation in acidic hydrolytic and oxidative stress conditions. Three new degradation impurities have been identified and characterized with the help of LC-Q-TOF-MS with accurate mass measurement and their putative structures have been proposed. Furthermore, for the first time, a possible degradation pathway has been established with mechanistic explanation. Moreover, the analytical method developed in this study will be of immense help for routine analysis of quality control and stability study samples of venetoclax in industry and research laboratories.
\end{abstract}

Keywords: Venetoclax, Analytical assay method, Validation, Degradation product, Characterization, LC-Q-TOF-MS

\section{Introduction}

Venetoclax (VEN) is a selective, novel, and orally active B-cell lymphoma 2 (Bcl-2) protein inhibitor very recently approved by the United States Food and Drug Administration (USFDA) to treat chronic lymphocytic leukemia and other hematological malignancies (Mato et al. 2018).

\footnotetext{
* Correspondence: psg725@gmail.com

National Institute of Pharmaceutical Education and Research-Ahmedabad (NIPER-A), An Institute of National Importance, Government of India, Department of Pharmaceuticals, Ministry of Chemicals and Fertilizers, Opp. Airforce Station, Palaj, Gandhinagar, Gujarat 382355, India
}

Chemically VEN belongs to biaryl acylsulfonamide class of anticancer molecule indicated for the treatment in adult cancer patients with $17 \mathrm{p}$ deletion (chromosome abnormality) or tumor suppression gene TP53 mutation or chemo-immunotherapy resistance. Overexpression of Bcl-2 protein results in the resistance of cancerous cells to apoptosis and hence, it is considered an important target for anticancer chemotherapy. VEN selectively binds to Bcl-2 protein and helps to restore apoptosis process by displacing proapoptotic proteins triggering permeability of outer membrane of mitochondria and
Springer Open (c) The Author(s). 2020 Open Access This article is licensed under a Creative Commons Attribution 4.0 International License, which permits use, sharing, adaptation, distribution and reproduction in any medium or format, as long as you give appropriate credit to the original author(s) and the source, provide a link to the Creative Commons licence, and indicate if changes were made. The images or other third party material in this article are included in the article's Creative Commons licence, unless indicated otherwise in a credit line to the material. If material is not included in the article's Creative Commons licence and your intended use is not permitted by statutory regulation or exceeds the permitted use, you will need to obtain permission directly from the copyright holder. To view a copy of this licence, visit http://creativecommons.org/licenses/by/4.0/. 
the activation of caspases (Žigart and Časar 2019; Roberts et al. 2016).

Globally, researchers are engaged in a continuous effort to discover anticancer drugs with a much higher safety profile (Jain et al. 2019; Sharma et al. 2019). Postmarketing surveillance of any drugs depends on its acceptability based on risk to benefit ratio. When risk outweighs the benefits, withdrawal of an already marketed drug is warranted. Presence of impurity is the primary cause of increased risk in a drug substance or drug product. With the discovery of newer molecules, it is of great importance to establish advanced analytical techniques for quantification of the drugs as well as their related impurities to address the prospective regulatory queries even if it is already in the market (Sahu and Sengupta 2020; Sharma et al. 2020; Gousuddin et al. 2017). Forced degradation is a strategy employed to cause stress decomposition of a molecule to generate degradation impurities for their subsequent identification. It is carried out at conditions more severe than accelerated conditions, which further help in evaluating the stability of a molecule (Inturi et al. 2018; Blessy et al. 2014). Stability is the ability of drugs in bulk form and their pharmaceutical product to remain within the specifications to maintain its purity, strength, quality and identity throughout their retest or shelf-life period. Assessment of degradation impurities through stress testing is an obvious requirement in a drug development program that helps in understanding the degradation behavior of a drug (Brümmer 2011; Sengupta et al. 2018). It also provides physicochemical and stereochemical stability of bulk drug and its formulation. According to International Council for Harmonisation of Technical Requirements for Pharmaceuticals for Human Use $(\mathrm{ICH})$ and other regulatory guidelines, it is a mandatory requirement to perform stress studies and develop stability indicating assay method before filing the registration dossier (Inturi et al. 2018). This study also helps in selecting appropriate dosage form and improvement in the production and packaging process (Hotha et al. 2013; Bhavsar et al. 2016). Stress studies at the developmental stage give a database that helps to select an excipient for further formulation development, container and closure system selection and also modification in storage conditions (Bajaj et al. 2012; Alsante et al. 2007). As a whole, stress studies are considered an essential part of the drug development cycle. Among all the sophisticated techniques chromatographic retention assisted mass spectrometry including Q-TOF is considered an excellent tool in characterization of unknown drug-related impurities with high selectivity and sensitivity (Watkins 2020; Chang et al. 2018; Kitagawa 2019).

Various analytical techniques have been reported for quantification of VEN. Liu et al reported a high performance liquid chromatography (HPLC) and liquid chromatography-mass spectrometry (LC-MS) method for absorption and metabolism study of the drug (Liu et al. 2017). However, a literature search revealed that there is no analytical assay method reported for quantification of VEN in presence of its degradation impurities. Therefore, we aimed to perform forced degradation of VEN and development of a quantitative analytical method in presence of its degradation products. Moreover, we also aimed to identify and characterize the potential degradation impurities of VEN by LC-quadrupole-time of flight (Q-TOF)-MS analysis.

\section{Experimental \\ Chemicals}

VEN (purity $98.81 \%$ ) was procured from Clearsynth. Acetonitrile (ACN), hydrogen peroxide (30\%), and formic acid were obtained from Qualigens, Thermo Fischer Scientific. Ammonium formate was obtained from Sigma Aldrich. Sodium hydroxide $(\mathrm{NaOH})$ was procured from Fischer scientific. Hydrochloric acid $(\mathrm{HCl})$ was purchased from Merck. For buffer and sample preparation, ultrapure water from Milli Q system (Millipore, USA) was collected.

\section{Instrumentation}

The HPLC system (Agilent) used for method development of VEN was comprising of binary pumps, column oven, autosampler, and diode array detector. OpenLab software was used for data collection and acquisition for report generation. LC-Q-TOF-MS system employed for characterizing the degradation impurities was comprising of an HPLC system (Agilent) connected to Q-TOF mass spectrometer (Agilent 6545 series) through an ESI interface ionization source. Mass Hunter software was employed for data processing and acquisition. Photolytic stress experiment was performed using a photostability chamber (Newtronic Life care). Hydrolytic degradation study was performed in a Radleys apparatus (Essex UK). A thermolytic stress study was conducted using a hot air oven (Heratherm, Thermo Scientific). For properly dissolving the sample, an ultra sonicator (Antech Scientific) was used. The $\mathrm{pH}$ meter of Eutech Instruments was employed for $\mathrm{pH}$ adjustment of stress samples and mobile phases.

\section{Chromatographic conditions}

Liquid chromatographic separation was achieved through an Agilent Zorbax eclipse plus C18 column $(250 \mathrm{X} 4.6 \mathrm{~mm} ; 5 \mu \mathrm{m})$ using ammonium formate $(10$ $\mathrm{mM}, \mathrm{pH} 5$ adjusted with formic acid): $\mathrm{ACN}$ as mobile phase at ambient temperature and a flow rate of $1 \mathrm{~mL} /$ min. Mobile phase was freshly prepared each time before the analysis. All separations were done at ambient 
temperature. The run time was optimized to $30 \mathrm{~min}$ in a gradient program $\left(\mathrm{T}_{\min } / \% \mathrm{ACN}\right.$ : 0/60, 3/60, 17/90, 20/90, $25 / 60,30 / 60)$ for separation of VEN and its degradation products. The column was kept at $30^{\circ} \mathrm{C}$ and analytes were detected at a wavelength of $286 \mathrm{~nm}$. A10 $\mu \mathrm{L}$ injection volume was sufficient for detection of VEN and its degradation products (DPs).

\section{Preparation of drug solution}

About $5 \mathrm{mg}$ of VEN was weighed and transferred to a $10 \mathrm{~mL}$ volumetric flask to which $5 \mathrm{~mL}$ of $\mathrm{ACN}$ was added and sonicated for $5 \mathrm{~min}$. Thereafter, the volume was made up to $10 \mathrm{~mL}$ with ACN to make a stock solution of about $500 \mu \mathrm{g} / \mathrm{mL}$. From this stock solution, $4 \mathrm{~mL}$ was diluted up to $10 \mathrm{~mL}$ with $\mathrm{ACN}$ to give a final working solution of about $400 \mu \mathrm{g} / \mathrm{mL}$, which was used for method development.

\section{LC-MS conditions}

The LC-MS/MS analysis of VEN was carried out in ESI positive mode. Fragmentor voltage was set at $130 \mathrm{~V}$, capillary voltage at $3500 \mathrm{~V}$, skimmer voltage at $64 \mathrm{~V}$, collision energy at $30 \mathrm{eV}$, drying gas temperature at $320{ }^{\circ} \mathrm{C}$ (8 L/min), nebulising gas pressure at $35 \mathrm{psi}$, sheath gas temperature and flow at $350^{\circ} \mathrm{C}$ and $11 \mathrm{~L} / \mathrm{min}$, respectively. Nitrogen was used as drying, nebulizing and collision gas. The liquid chromatographic separation was done on Agilent Poroshell 120 SB C18 column by using ammonium formate $(10 \mathrm{mM}$, pH 5 adjusted with formic acid): $\mathrm{ACN}$ as mobile phase at ambient temperature and $0.4 \mathrm{~mL} / \mathrm{min}$ flow. A sample volume of $2 \mu \mathrm{L}$ was injected for each run.

\section{Stress studies}

Stress studies on VEN were performed by applying different stress conditions given in ICH Q1A (R2) guideline (ICH 2003). All the stress experiments were performed on $1 \mathrm{mg} / \mathrm{mL}$ solution of VEN. It was subjected to various stress conditions like hydrolysis, oxidation, thermal and photolytic degradation. Acidic, basic and neutral hydrolysis was performed with $2 \mathrm{~N} \mathrm{HCl}, 2 \mathrm{~N} \mathrm{NaOH}$, and water, respectively at $70{ }^{\circ} \mathrm{C}$ for $72 \mathrm{hr}$. Oxidative degradation was performed by exposing the drug to $0.3 \%$ hydrogen peroxide $\left(\mathrm{H}_{2} \mathrm{O}_{2}\right)$ at ambient conditions for 48 hr. For thermolytic stress, the drug was uniformly spread on a Petri plate and kept in a hot air oven at $80{ }^{\circ} \mathrm{C}$ for 7 days. Photolysis of VEN was carried out in a photostability chamber by keeping solid form of the drug to ultraviolet (UV) and fluorescence light with a minimum intensity of $200 \mathrm{Whr} / \mathrm{m}^{2}$ and 1.2 million.lux.hr, respectively. The maximum UV and fluorescence light exposure was $400 \mathrm{Whr} / \mathrm{m}^{2}$ and 6 million.Lux.hr, respectively. For photodegradation, control samples covered with aluminum foil (to prevent the exposure of light) were also placed along with stress samples in the photostability chamber. All stress samples were compared with blank and control samples exposed to the same conditions. The optimized stress conditions applied in stress degradation of VEN are summarized in Table 1.

\section{Generation of forced degraded samples Acidic hydrolysis}

Acidic hydrolytic stress sample was prepared by weighing about $5 \mathrm{mg}$ of VEN and transferred to Radleys tube to which $5 \mathrm{~mL}$ of $\mathrm{ACN}$ was added and sonicated for 2 min. To this drug solution, $5 \mathrm{~mL}$ of $2 \mathrm{~N} \mathrm{HCl}$ was added and final concentration of stress sample was $500 \mu \mathrm{g} / \mathrm{mL}$. A blank sample was also prepared by taking $5 \mathrm{~mL}$ of 2 $\mathrm{N} \mathrm{HCl}$ and $5 \mathrm{~mL}$ of $\mathrm{ACN}$ to check if any interference is present due to the solvent used for sample preparation. Both sample and blank solutions were placed on Radleys apparatus with continuous stirring with a magnetic bead at $300 \mathrm{rpm}$ and $70{ }^{\circ} \mathrm{C}$ for $72 \mathrm{hrs}$.

\section{Basic hydrolysis}

Basic hydrolytic stress sample was prepared by weighing $5 \mathrm{mg}$ of VEN and transferred to Radleys tube to which 5 $\mathrm{mL}$ of ACN was added and sonicated for $2 \mathrm{~min}$. To this drug solution, $5 \mathrm{~mL}$ of $2 \mathrm{~N} \mathrm{NaOH}$ was added and final concentration of stress sample was $500 \mu \mathrm{g} / \mathrm{mL}$. A blank sample was also prepared by taking $5 \mathrm{~mL}$ of $2 \mathrm{~N} \mathrm{NaOH}$ and $5 \mathrm{~mL}$ of $\mathrm{ACN}$ to check if any interference is present due to the solvent used for sample preparation. Both sample and blank solutions were placed on Radleys apparatus with continuous stirring with a magnetic bead at $300 \mathrm{rpm}$ and $70{ }^{\circ} \mathrm{C}$ for $72 \mathrm{hrs}$.

Table 1 Summary of degradation behaviour of VEN

\begin{tabular}{|c|c|c|c|c|}
\hline Sr.no. & Degradation study & Conditions of stress study & $\%$ Drug degraded & Retention time of degradants (minutes) \\
\hline 1. & Acidic hydrolysis & $2 \mathrm{~N} \mathrm{HCl}$ for $72 \mathrm{hrs}$ & $7.31 \%$ & DP1 at $16.1 \mathrm{~min}$ \\
\hline 2. & Basic hydrolysis & $2 \mathrm{~N} \mathrm{NaOH}$ for $72 \mathrm{hrs}$ & No degradation & - \\
\hline 3. & Neutral hydrolysis & Water for $72 \mathrm{hrs}$ & No degradation & - \\
\hline 4. & Oxidative degradation & $0.3 \% \mathrm{H}_{2} \mathrm{O}_{2}$ for $48 \mathrm{hrs}$ & $44.46 \%$ & DP2 at $4.2 \mathrm{~min}$ and DP3 at $6.5 \mathrm{~min}$. \\
\hline 5. & Thermal degradation & $80^{\circ} \mathrm{C}$ for 7 days & No degradation & - \\
\hline 6. & Photolytic degradation & UV and fluorescent light for 5 cycles & No degradation & - \\
\hline
\end{tabular}




\section{Neutral hydrolysis}

Neutral hydrolytic stress sample was prepared by weighing $5 \mathrm{mg}$ of VEN and transferred to Radleys tube to which $5 \mathrm{~mL}$ of ACN was added and sonicated for $2 \mathrm{~min}$. To this drug solution, $5 \mathrm{~mL}$ of Milli Q water was added and final concentration of stress sample was $500 \mu \mathrm{g} / \mathrm{mL}$. A blank sample was also prepared by taking $5 \mathrm{~mL}$ of water and $5 \mathrm{~mL}$ of $\mathrm{ACN}$ to check if any interference is present due to the solvent used for sample preparation. Both sample and blank solutions were placed on Radleys apparatus with continuous stirring with a magnetic bead at $300 \mathrm{rpm}$ and $70{ }^{\circ} \mathrm{C}$ for $72 \mathrm{hrs}$.

\section{Oxidative degradation}

Oxidative stress sample was prepared by weighing $5 \mathrm{mg}$ of VEN and transferred to $10 \mathrm{~mL}$ of volumetric flask to which $5 \mathrm{~mL}$ of ACN was added and sonicated for $2 \mathrm{~min}$. To this drug solution, $5 \mathrm{~mL}$ of $0.3 \% \mathrm{H}_{2} \mathrm{O}_{2}$ was added and final concentration of stress sample was $500 \mu \mathrm{g} / \mathrm{mL}$. A blank sample was also prepared by taking $5 \mathrm{~mL}$ of
$0.3 \% \mathrm{H}_{2} \mathrm{O}_{2}$ and $5 \mathrm{~mL}$ of $\mathrm{ACN}$ to check if any interference is present due to the solvent used for sample preparation. Both sample and blank volumetric flask are kept at room temperature in a dark place for 5 days.

\section{Thermal degradation}

For thermal stress study, about $5 \mathrm{mg}$ of VEN was taken and placed in a Petri plate and it was uniformly spread on the surface of Petri plate with the help of a spatula. After that, it was covered with a lid and kept in the hot air oven at $80{ }^{\circ} \mathrm{C}$ for 7 days.

\section{Photolytic degradation}

For photolytic stress study, about $5 \mathrm{mg}$ of VEN was taken and placed in Petri plates and it was uniformly spread on the surface of Petri plates with the help of a spatula. For solid control, $5 \mathrm{mg}$ of drug was placed in a Petri plate and it was wrapped with aluminum foil. All Petri plates were placed in photostability chamber. Two Petri plates were kept in UV chamber, out of which one
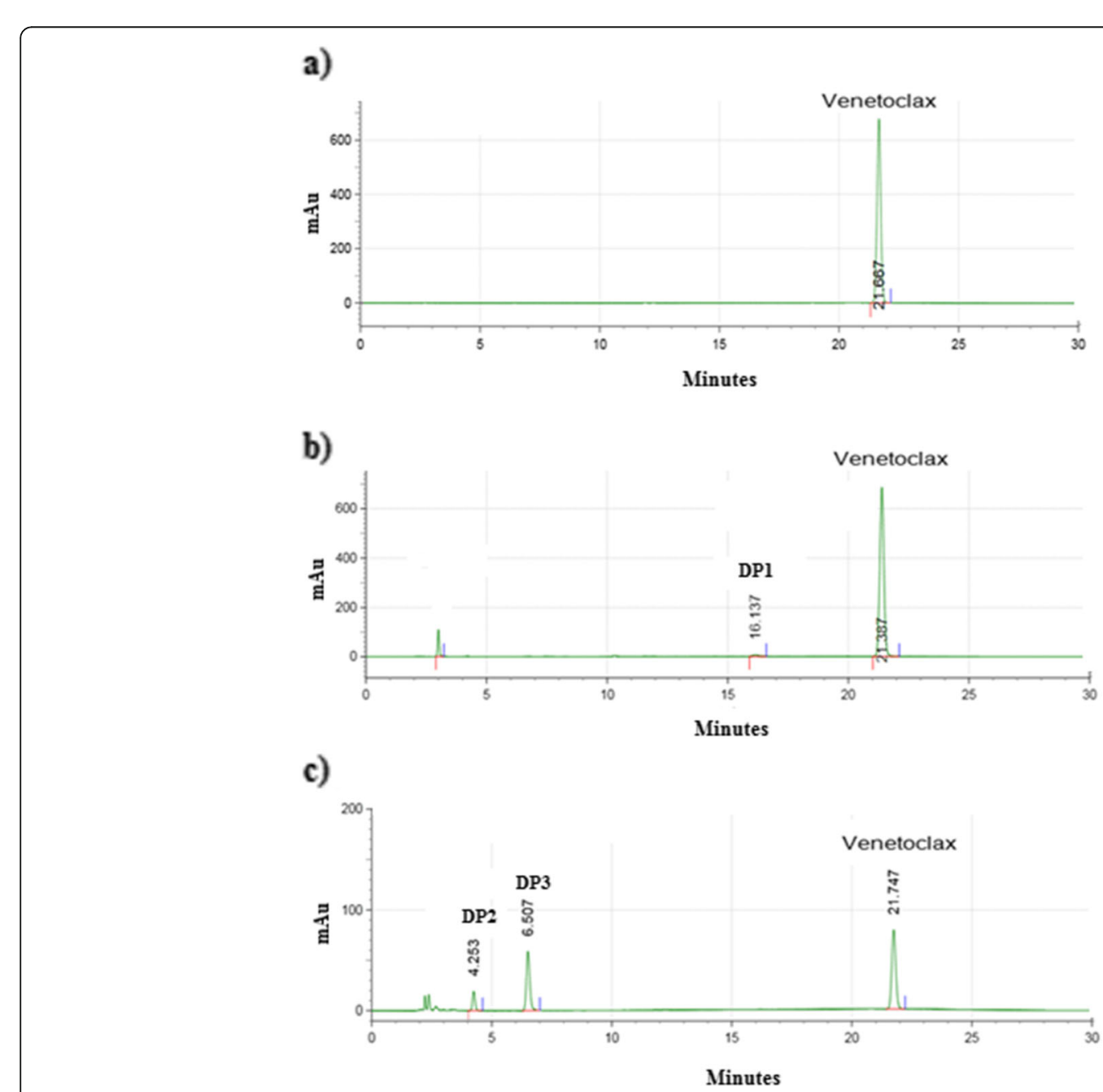

Fig. $1 \mathrm{HPLC}$ chromatogram of a) Standard b) Acidic hydrolysis stressed c) Oxidative stressed sample 
was control and the light exposure was from 200 to 400 wat.hr $/ \mathrm{m}^{2}$. Another two Petri plates were kept in fluorescent chamber and exposed to 1.2 to 6 million.Lux.hr illumination.

\section{Preparation of stress sample for analysis}

ACN was used as a solvent for preparation of stress degraded samples. $1 \mathrm{~mL}$ of acid and base degradation sample was withdrawn at different time points and neutralized by $2 \mathrm{~N} \mathrm{NaOH}$ and $2 \mathrm{~N} \mathrm{HCl}$, respectively with the aid of $\mathrm{pH}$ paper. Each sample after stress exposure was subjected to dilution for achieving a final concentration of $400 \mu \mathrm{g} / \mathrm{mL}$. Samples were then filtered $(0.22 \mu$ membrane filter)and injected into the analytical systems.

\section{Method validation}

The developed assay method was validated according to the ICH Q 2 (R1) guidelines. The linearity of the method was established by taking seven calibration standards in triplicate $(\mathrm{n}=3)$ from 50 to $600 \mu \mathrm{g} / \mathrm{mL}$. Intrabatch and inter-batch precision was evaluated by injecting six replicates of $400 \mu \mathrm{g} / \mathrm{mL}$ of one batch in a single day and twelve replicates of $400 \mu \mathrm{g} / \mathrm{mL}$ between two different batches in two different days, respectively. Accuracy of the method was determined in terms of recovery where three different concentration $(80 \%, 100 \%, 120 \%$ of 400 $\mu \mathrm{g} / \mathrm{mL})$ of the drug was spiked $(\mathrm{n}=3)$ in the mixtures fortified with excipients. Then the \% recovery was calculated by comparing the area of spiked samples against standard samples.

\section{Results and discussions \\ Optimization of HPLC method}

Preliminary chromatographic separations were carried out by using different columns, different mobile phases, at different $\mathrm{pH}$ and modifying different mobile phase ratios to resolve VEN and its degradation products, have good peak shape and symmetry. Initial runs were carried out in an isocratic mode to check the peak purity of VEN and to select the appropriate buffer system. Further trials were carried out in gradient mode on Waters Reliant C18 column (250 mm x $4.6 \mathrm{~mm}, 5 \mu \mathrm{m})$ using 10 $\mathrm{mM}$ ammonium acetate: $\mathrm{ACN}$ as a mobile phase. In this trial, poor peak shape, baseline noise and poor resolution were observed. Finally, the method was optimized by changing the column to Zorbax eclipse C18 column (250 mm x $4.6 \mathrm{~mm}, 5 \mu \mathrm{m}$ ) using ammonium formate (10 mM, pH 5 adjusted with formic acid): ACN as mobile phase at ambient temperature in a linear gradient program $\left(\mathrm{T}_{\min } / \% \mathrm{ACN}\right.$ : $0 / 60,3 / 60,17 / 90,20 / 90,25 / 60$, 30/60). The column was kept at $30{ }^{\circ} \mathrm{C}$. At $286 \mathrm{~nm}$ wavelength, VEN and its DPs were detected and quantified well. An injection volume of $10 \mu \mathrm{L}$ was selected for analyzing VEN and its DPs. Gradient program provided a better separation of all peaks as compared to isocratic program. By applying this chromatographic method, VEN and all degradation products were well separated with good peak shapes which are shown in Figure 1.

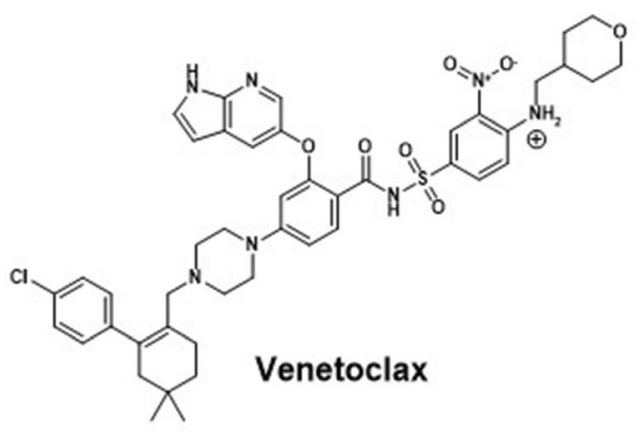<smiles>CC(C)CCCCN1CCN(c2ccc(C(=O)O)c(Oc3cnc4[nH]ccc4c3)c2)CC1CC1=CCC(C)(C)C1c1ccc(Cl)cc1</smiles>
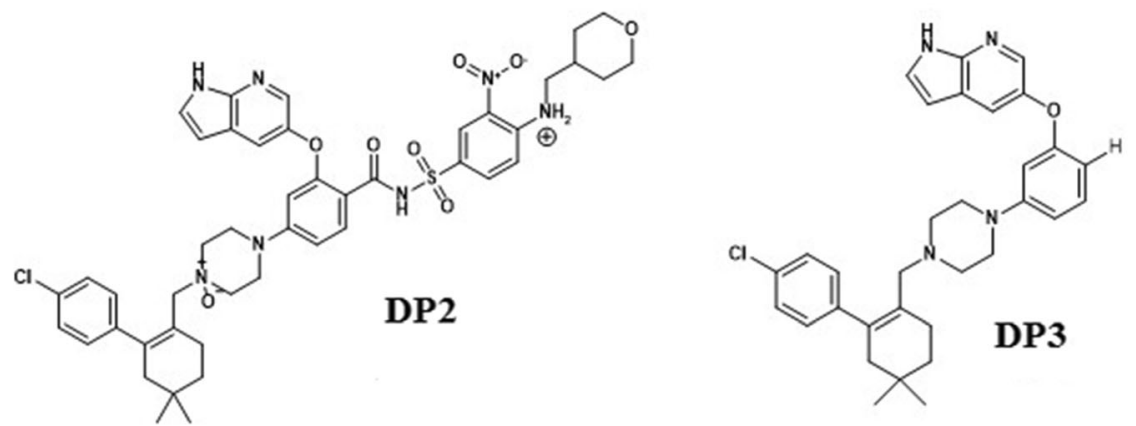

Fig. 2 Structures of VEN and its DPs 
a)

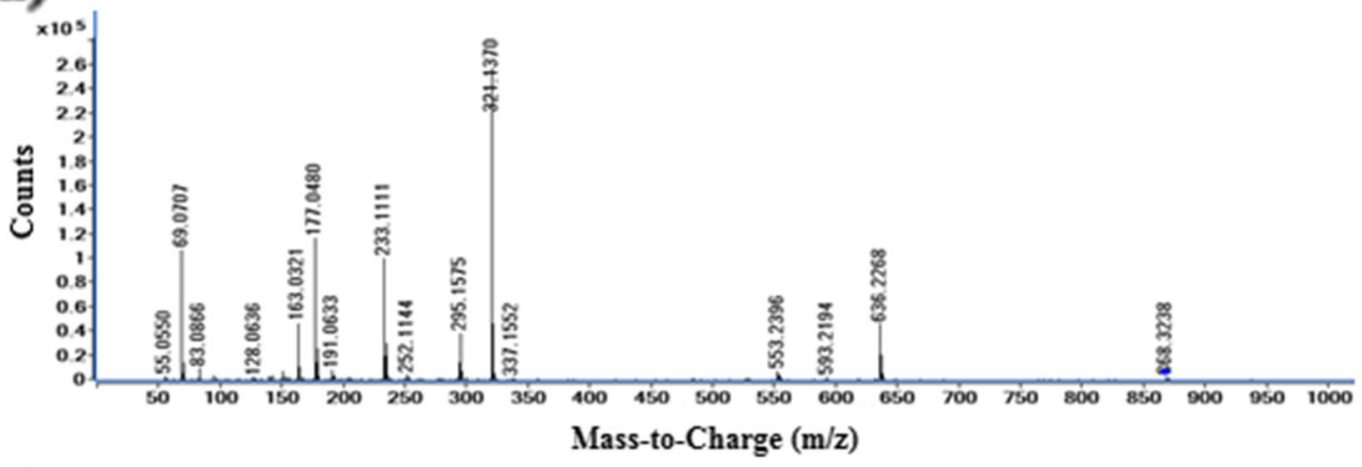

b)

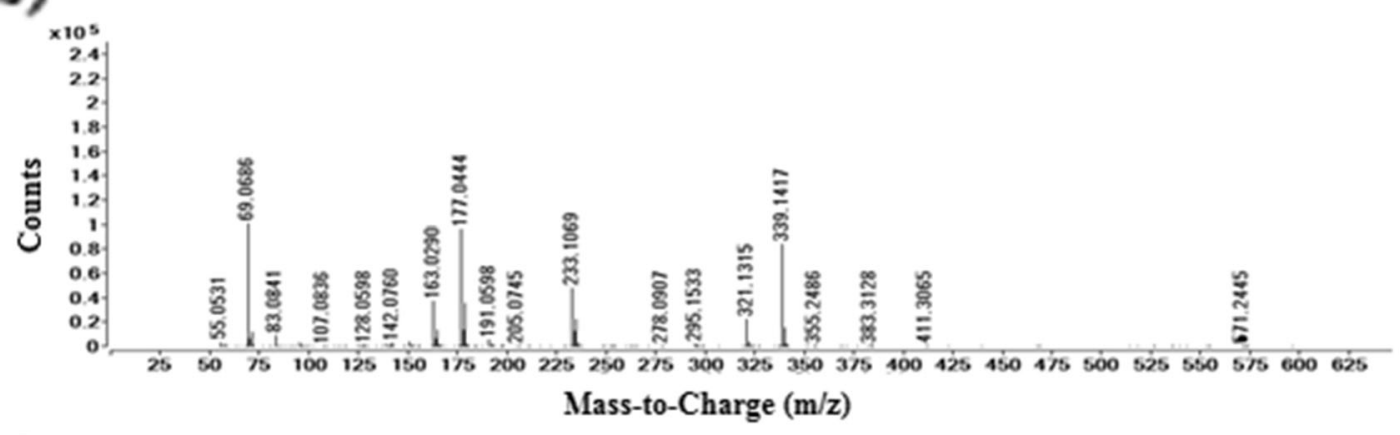

c)

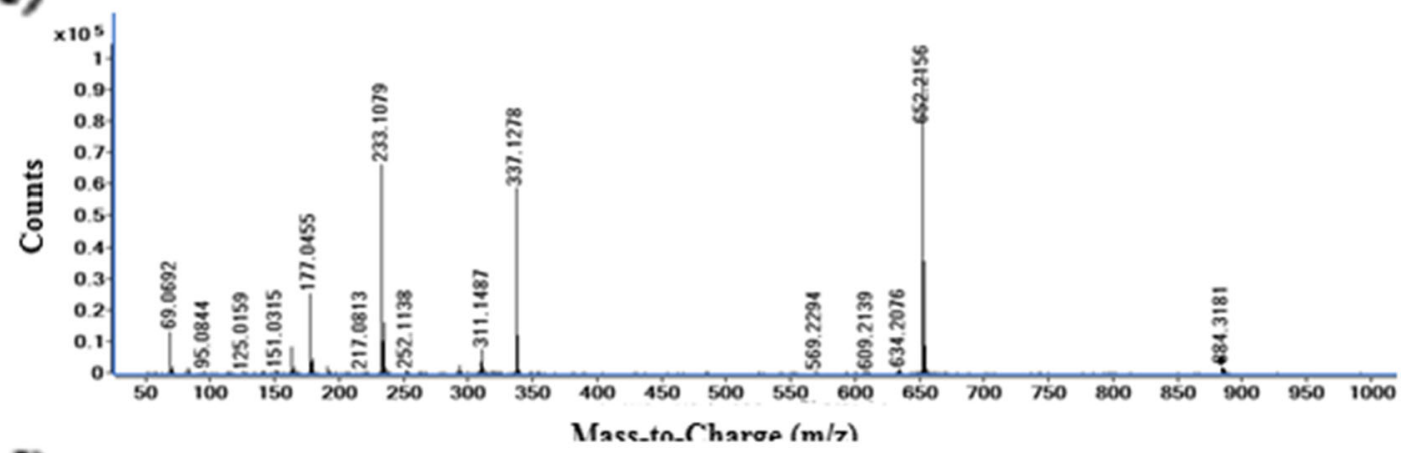

d)

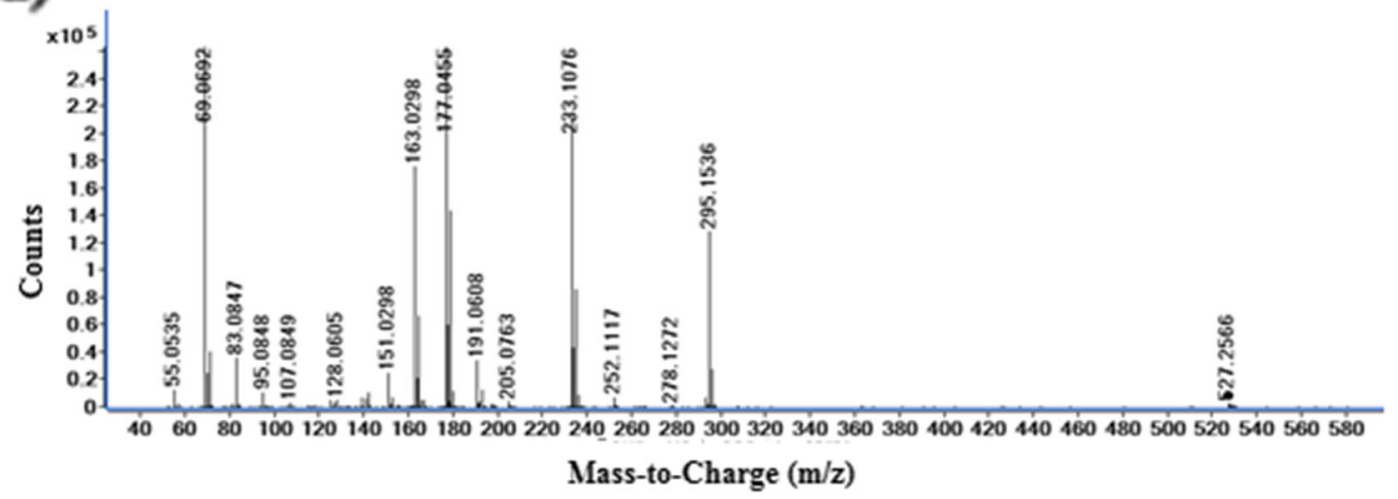

Fig. 3 LC-MS/MS spectra of a) VEN b) DP1 c) DP2 d) DP3 


\section{Degradation pattern of VEN}

The degradation pattern was studied by injecting the stressed samples to HPLC and further resolving the peaks of VEN and all DPs. VEN was degraded in acidic hydrolysis and oxidative stress. The drug was stable in basic hydrolysis, neutral hydrolysis, thermal and photolytic conditions. DP1 was formed in acidic hydrolysis. Moreover, two separate DPs (DP2 and DP3) were also observed in oxidative degradation.

\section{Structural characterization of VEN and its DPs}

The degradation impurities generated in acidic hydrolysis and oxidative stress were subjected to mass spectrometric analysis. The $\mathrm{m} / \mathrm{z}$ ratio and mass fragmentation patterns were studied for VEN and its DPs. The structures were proposed based on their accurate mass measurement and calculating ppm error. Structures of VEN and all its DPs are shown in Figure 2. Moreover, MS/MS spectrum of VEN and the DPs are shown in Figure 3.

\section{MS/MS profiling of VEN}

MS/MS spectrum of VEN (Figure 3a) showed protonated molecular ion at $\mathrm{m} / \mathrm{z} 868.3238\left(\mathrm{C}_{45} \mathrm{H}_{51} \mathrm{ClN}_{7} \mathrm{O}_{7} \mathrm{~S}^{+}\right)$ in positive ionization mode. Primary fragment ion formed at $\mathrm{m} / \mathrm{z} 636$ (losing chlorophenyldimethyl- cyclohexenyl moiety), 553 (losing benzene sulfonamide), 321 (losing chlorophenyldimethyl-cyclohexenyl moiety from $\mathrm{m} / \mathrm{z}$ 553), 295 (losing benzene sulfonamide moiety from $\mathrm{m} / \mathrm{z}$ 636), 233 (losing pyrrolopyridine-4-piperazine phenyl moiety from $\mathrm{m} / \mathrm{z} 553$ ), 191 (losing cyclopropane moiety from $\mathrm{m} / \mathrm{z} 233$ ), 177 (losing methylene group from m/z 191), 163 (losing methylene group from $\mathrm{m} / \mathrm{z}$ 177). Moreover, additional fragments were also observed at $\mathrm{m} / \mathrm{z} 151,83$ and 69 . The fragmentation patterns are shown in Scheme 1 . The elemental composition was confirmed by accurate mass measurement as mentioned in Table 2.

\section{MS/MS profiling of DP1}

MS/MS spectrum of DP1 formed in acidic hydrolysis (Figure $3 \mathrm{~b}$ ) showed protonated molecular ion at $\mathrm{m} / \mathrm{z}$ value of 571.2445 with plausible chemical formula $\mathrm{C}_{33} \mathrm{H}_{36} \mathrm{ClN}_{4} \mathrm{O}_{3}{ }^{+}$. The fragmentation pattern of DP2 (Scheme 2) revealed major product ions at $\mathrm{m} / \mathrm{z} 339$, 321, 233, 177, 163 and 69. Elemental compositions of DP1 and its product ions have been ensured by accurate mass measurements as shown in Table 2. DP1 was identified as 2-((1H-pyrrolo[2,3-b]pyridin-5-yl)oxy)-4-(4((4'-choro-5,5-dimethyl-3,4,5,6-tetrahydro-[1,1'-biphenyl]2-yl)methyl)piperazin-1-yl)benzoic acid.

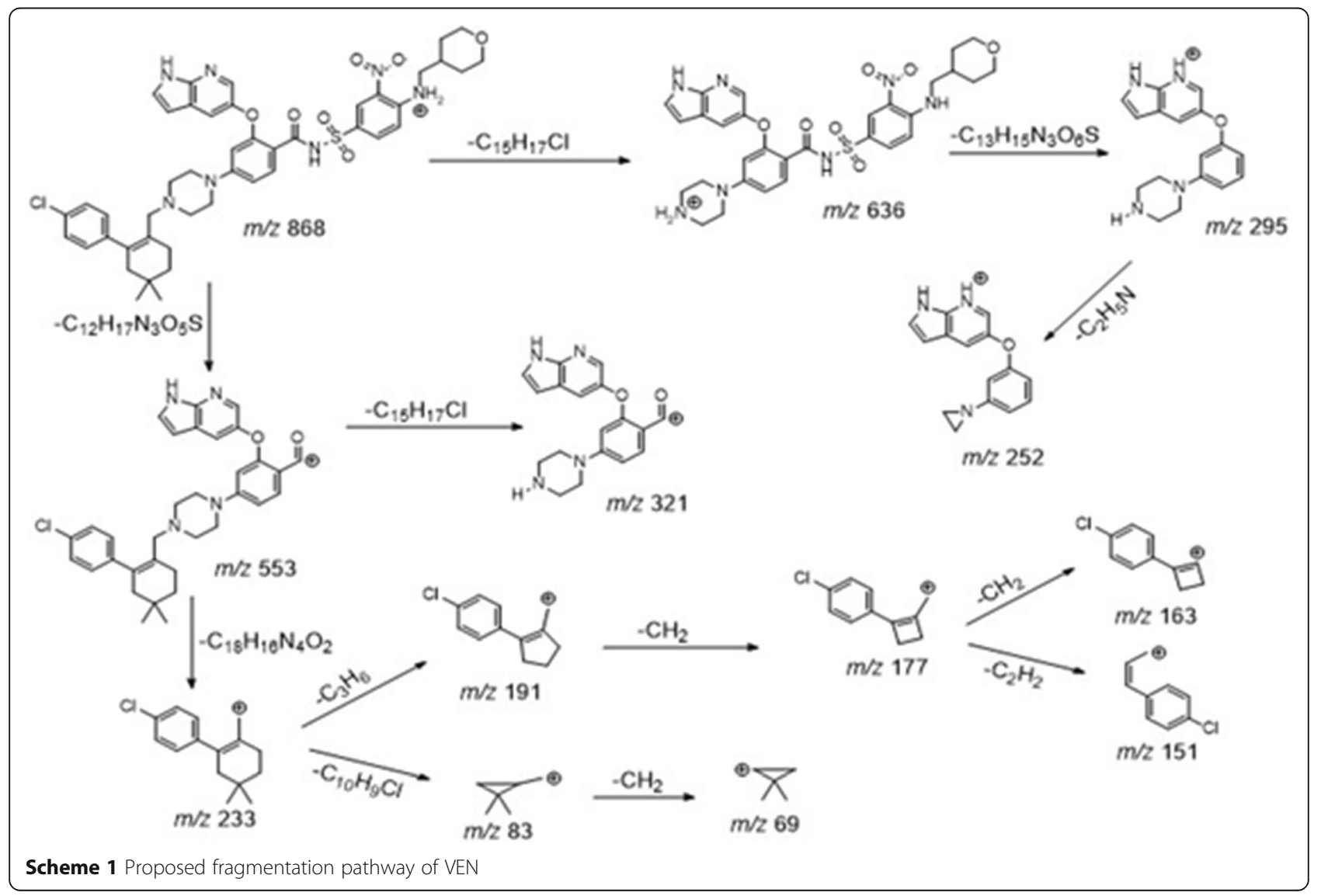


Table 2 HRMS data of product ions of protonated VEN and its degradation products

\begin{tabular}{|c|c|c|c|c|}
\hline & Chemical formula & MS/TOF mass data & Exact mass of most probable structure & ppm error \\
\hline \multirow[t]{13}{*}{ VEN } & $\mathrm{C}_{45} \mathrm{H}_{51} \mathrm{ClN}_{7} \mathrm{O}_{7} \mathrm{~S}^{+}$ & 868.3238 & 868.3254 & -1.84 \\
\hline & $\mathrm{C}_{30} \mathrm{H}_{34} \mathrm{~N}_{7} \mathrm{O}_{7} \mathrm{~S}^{+}$ & 636.2268 & 636.2235 & 5.18 \\
\hline & $\mathrm{C}_{33} \mathrm{H}_{34} \mathrm{ClN}_{4} \mathrm{O}_{2}$ & 553.2396 & 553.2365 & 5.60 \\
\hline & $\mathrm{C}_{18} \mathrm{H}_{17} \mathrm{~N}_{4} \mathrm{O}_{2}^{+}$ & 321.1370 & 321.1346 & 7.47 \\
\hline & $\mathrm{C}_{17} \mathrm{H}_{19} \mathrm{~N}_{4} \mathrm{O}^{+}$ & 295.1575 & 295.1553 & 7.45 \\
\hline & $\mathrm{C}_{15} \mathrm{H}_{14} \mathrm{~N}_{3} \mathrm{O}^{+}$ & 252.1144 & 252.1131 & 5.15 \\
\hline & $\mathrm{C}_{15} \mathrm{H}_{18} \mathrm{Cl}^{+}$ & 233.1111 & 233.1092 & 8.15 \\
\hline & $\mathrm{C}_{12} \mathrm{H}_{12} \mathrm{Cl}^{+}$ & 191.0633 & 191.0622 & 5.75 \\
\hline & $\mathrm{C}_{11} \mathrm{H}_{10} \mathrm{Cl}^{+}$ & 177.0480 & 177.0466 & 7.90 \\
\hline & $\mathrm{C}_{10} \mathrm{H}_{8} \mathrm{Cl}^{+}$ & 163.0321 & 163.0309 & 7.36 \\
\hline & $\mathrm{C}_{9} \mathrm{H}_{8} \mathrm{Cl}^{+}$ & 151.0321 & 151.0309 & 7.94 \\
\hline & $\mathrm{C}_{6} \mathrm{H}_{11}^{+}$ & 83.0866 & 83.0855 & 13.23 \\
\hline & $\mathrm{C}_{5} \mathrm{H}_{9}^{+}$ & 69.0707 & 69.0699 & 11.58 \\
\hline \multirow[t]{11}{*}{ DP1 } & $\mathrm{C}_{33} \mathrm{H}_{36} \mathrm{ClN}_{4} \mathrm{O}_{3}^{+}$ & 571.2445 & 571.2470 & -4.37 \\
\hline & $\mathrm{C}_{18} \mathrm{H}_{19} \mathrm{~N}_{4} \mathrm{O}_{3}^{+}$ & 339.1417 & 339.1452 & -10.32 \\
\hline & $\mathrm{C}_{18} \mathrm{H}_{17} \mathrm{~N}_{4} \mathrm{O}_{2}^{+}$ & 321.1315 & 321.1346 & -9.65 \\
\hline & $\mathrm{C}_{17} \mathrm{H}_{19} \mathrm{~N}_{4} \mathrm{O}^{+}$ & 295.1533 & 295.1553 & -6.77 \\
\hline & $\mathrm{C}_{15} \mathrm{H}_{14} \mathrm{~N}_{3} \mathrm{O}^{+}$ & 252.1144 & 252.1131 & 5.15 \\
\hline & $\mathrm{C}_{15} \mathrm{H}_{18} \mathrm{Cl}^{+}$ & 233.1069 & 233.1092 & -9.86 \\
\hline & $\mathrm{C}_{12} \mathrm{H}_{12} \mathrm{Cl}^{+}$ & 191.0598 & 191.0622 & -12.56 \\
\hline & $\mathrm{C}_{11} \mathrm{H}_{10} \mathrm{Cl}^{+}$ & 177.0444 & 177.0466 & -12.42 \\
\hline & $\mathrm{C}_{10} \mathrm{H}_{8} \mathrm{Cl}^{+}$ & 163.0290 & 163.0309 & -11.65 \\
\hline & $\mathrm{C}_{6} \mathrm{H}_{11}^{+}$ & 83.0841 & 83.0855 & -16.85 \\
\hline & $\mathrm{C}_{5} \mathrm{H}_{9}^{+}$ & 69.0686 & 69.0699 & -18.82 \\
\hline \multirow[t]{8}{*}{ DP2 } & $\mathrm{C}_{45} \mathrm{H}_{51} \mathrm{ClN}_{7} \mathrm{O}_{8} \mathrm{~S}^{+}$ & 884.3181 & 884.3203 & -2.48 \\
\hline & $\mathrm{C}_{30} \mathrm{H}_{34} \mathrm{~N}_{7} \mathrm{O}_{8} \mathrm{~S}^{+}$ & 652.2156 & 652.2184 & -4.29 \\
\hline & $\mathrm{C}_{18} \mathrm{H}_{17} \mathrm{~N}_{4} \mathrm{O}_{3}^{+}$ & 337.1278 & 337.1295 & -5.04 \\
\hline & $\mathrm{C}_{17} \mathrm{H}_{19} \mathrm{~N}_{4} \mathrm{O}_{2}^{+}$ & 311.1487 & 311.1503 & -5.14 \\
\hline & $\mathrm{C}_{15} \mathrm{H}_{18} \mathrm{Cl}^{+}$ & 233.1079 & 233.1092 & -5.57 \\
\hline & $\mathrm{C}_{11} \mathrm{H}_{10} \mathrm{Cl}^{+}$ & 177.0455 & 177.0466 & -6.21 \\
\hline & $\mathrm{C}_{9} \mathrm{H}_{8} \mathrm{Cl}^{+}$ & 151.0315 & 151.0309 & 3.97 \\
\hline & $\mathrm{C}_{5} \mathrm{H}_{9}^{+}$ & 69.0692 & 69.0699 & -10.13 \\
\hline \multirow[t]{10}{*}{ DP3 } & $\mathrm{C}_{32} \mathrm{H}_{36} \mathrm{ClN}_{4} \mathrm{O}^{+}$ & 527.2566 & 527.2572 & -1.13 \\
\hline & $\mathrm{C}_{17} \mathrm{H}_{19} \mathrm{~N}_{4} \mathrm{O}^{+}$ & 295.1536 & 295.1553 & -5.75 \\
\hline & $\mathrm{C}_{15} \mathrm{H}_{14} \mathrm{~N}_{3} \mathrm{O}^{+}$ & 252.1117 & 252.1131 & -5.55 \\
\hline & $\mathrm{C}_{15} \mathrm{H}_{18} \mathrm{Cl}^{+}$ & 233.1076 & 233.1092 & -6.86 \\
\hline & $\mathrm{C}_{12} \mathrm{H}_{12} \mathrm{Cl}^{+}$ & 191.0608 & 191.0622 & -7.32 \\
\hline & $\mathrm{C}_{11} \mathrm{H}_{10} \mathrm{Cl}^{+}$ & 177.0455 & 177.0466 & -6.21 \\
\hline & $\mathrm{C}_{10} \mathrm{H}_{8} \mathrm{Cl}^{+}$ & 163.0298 & 163.0309 & -6.74 \\
\hline & $\mathrm{C}_{9} \mathrm{H}_{8} \mathrm{Cl}^{+}$ & 163.0298 & 151.0309 & -7.28 \\
\hline & $\mathrm{C}_{6} \mathrm{H}_{11}^{+}$ & 83.0847 & 83.0855 & -9.62 \\
\hline & $\mathrm{C}_{5} \mathrm{H}_{9}^{+}$ & 69.0692 & 69.0699 & -10.13 \\
\hline
\end{tabular}



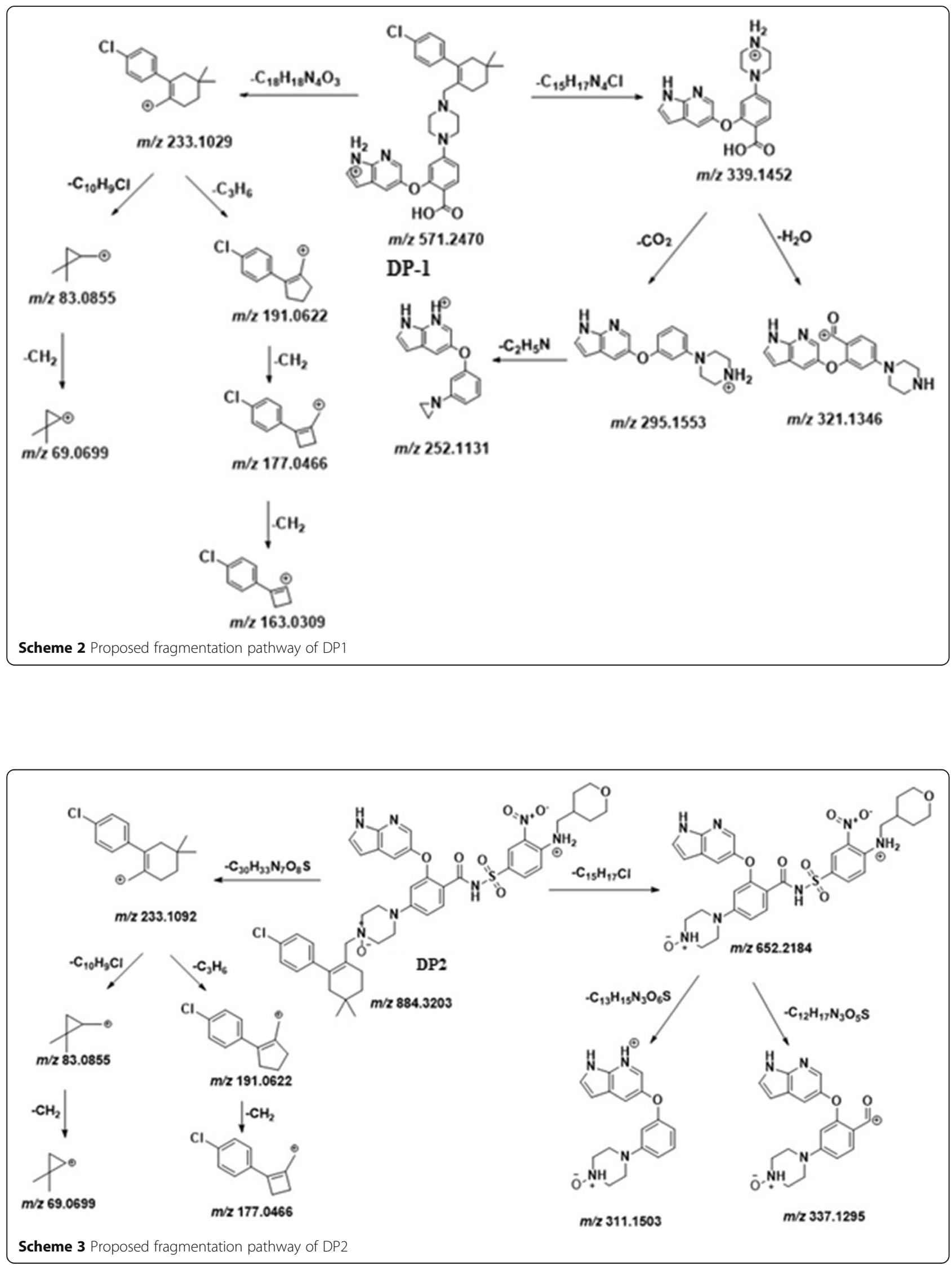


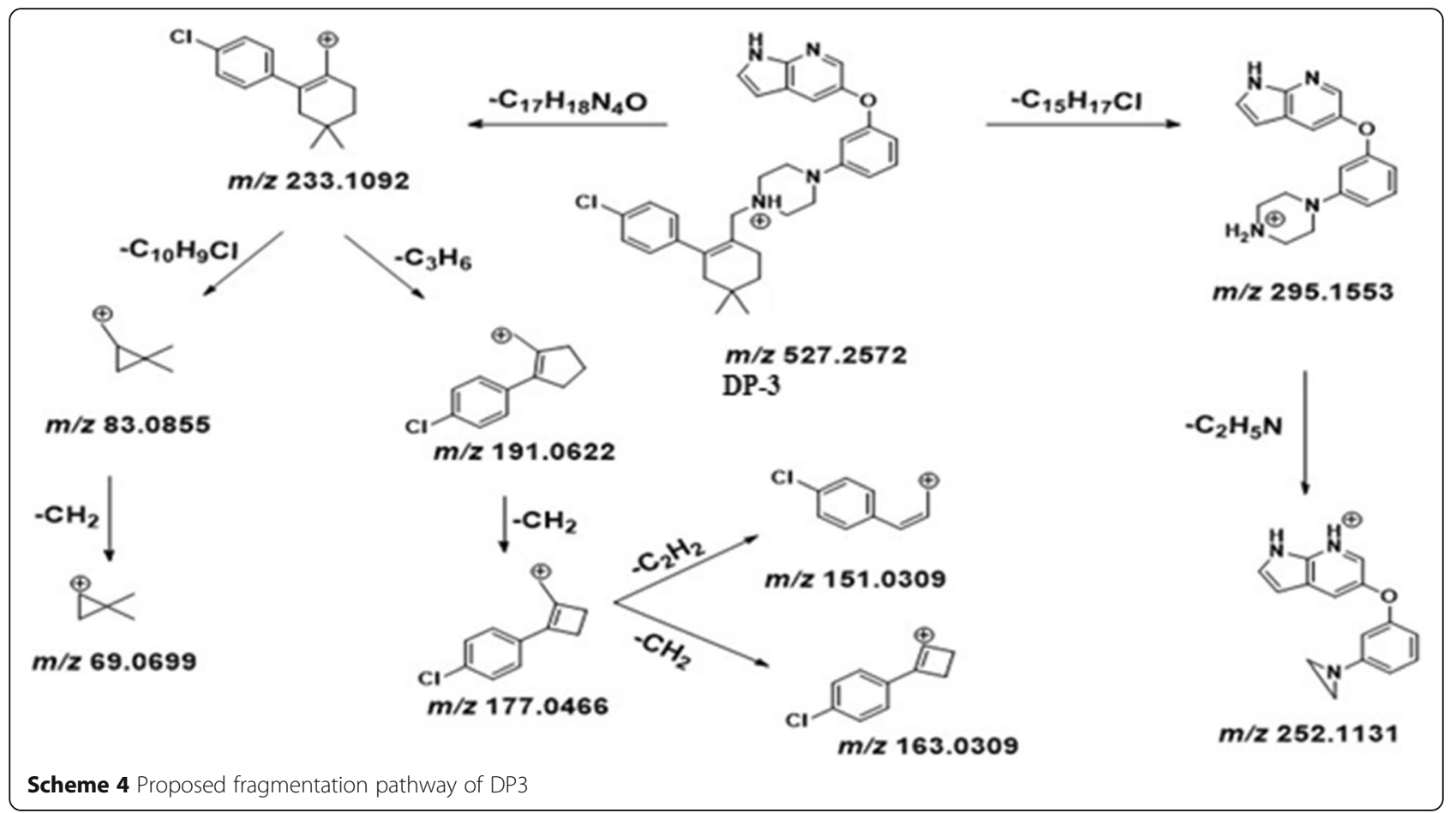

\section{MS/MS profiling of DP2}

MS/MS spectrum of DP2 formed in oxidative degradation (Figure 3c) showed protonated molecular ion at $\mathrm{m} / \mathrm{z}$ value of $884.3181\left(\mathrm{C}_{45} \mathrm{H}_{51} \mathrm{ClN}_{7} \mathrm{O}_{8} \mathrm{~S}^{+}\right)$in positive ion mode. The mass difference between VEN $(\mathrm{m} / \mathrm{z}$ $868)$ and DP2 (m/z 884) was 16 units. We proposed that there was an addition of an oxygen atom to form $\mathrm{N}$-oxide. The fragmentation pattern of DP2 is shown in Scheme 3 with major daughter ions at $\mathrm{m} / \mathrm{z}$ 652, 337, 233, 177, and 69. Characteristic fragment formed at $\mathrm{m} / \mathrm{z} 652$ (due to chlorophenyldimethyl-cyclohexenyl moiety loss and addition of an oxide ion to nitrogen of piperazine ring) confirms the production of $\mathrm{N}$ oxide. The elemental compositions of DP2 and its product ions have been ensured by accurate mass measurements (Table 2). DP2 was identified as 4-(3$((1 \mathrm{H}-\quad$ pyrrolo[2,3-b]pyridin-5-yl)oxy)-4-(((tetrahydro2H-pyran-4-yl)methyl)amino)phenyl) sulfonyl)carbamoyl)phenyl)-1-((4'-chloro-5,5-dimethyl-3,4,5,6-tetrahydro-[1,1'-biphenyl]-2-yl)methyl)piperazin-1-oxide.

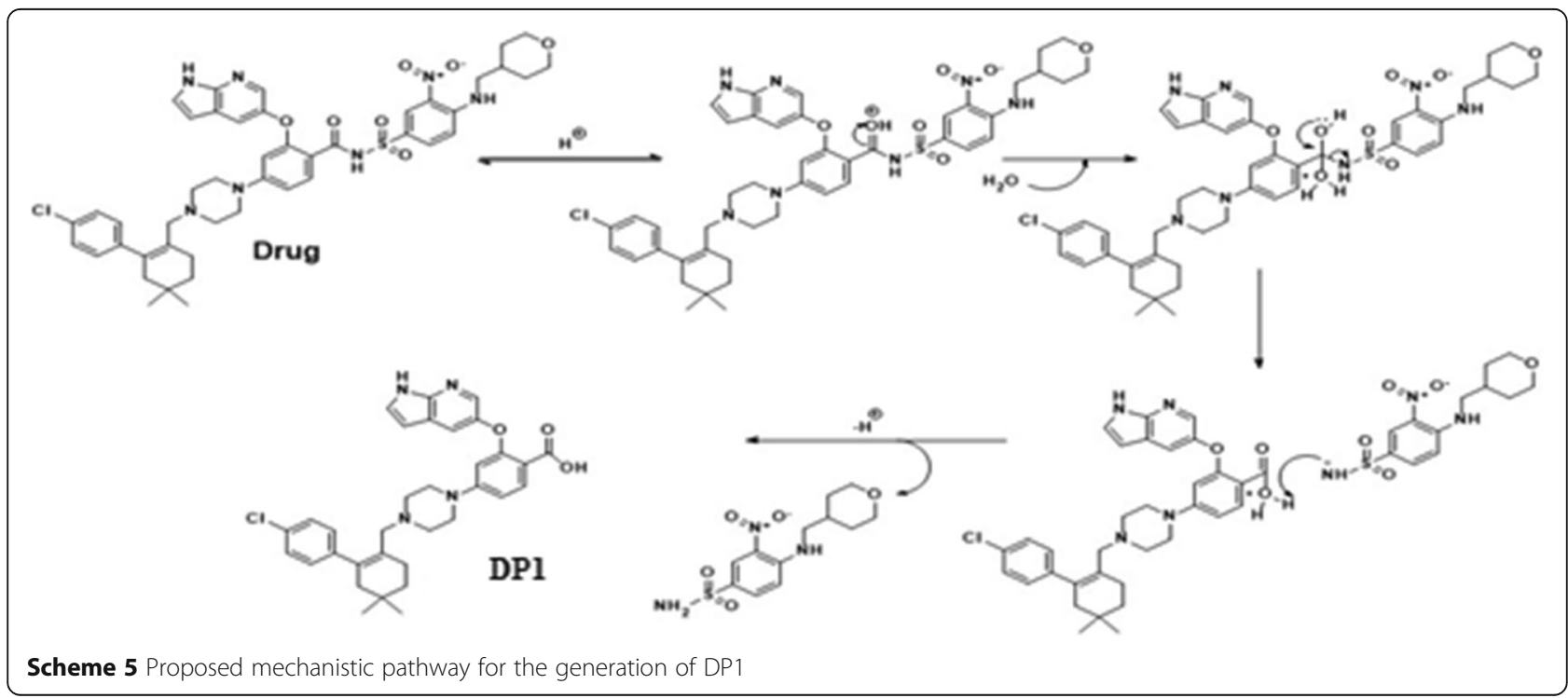




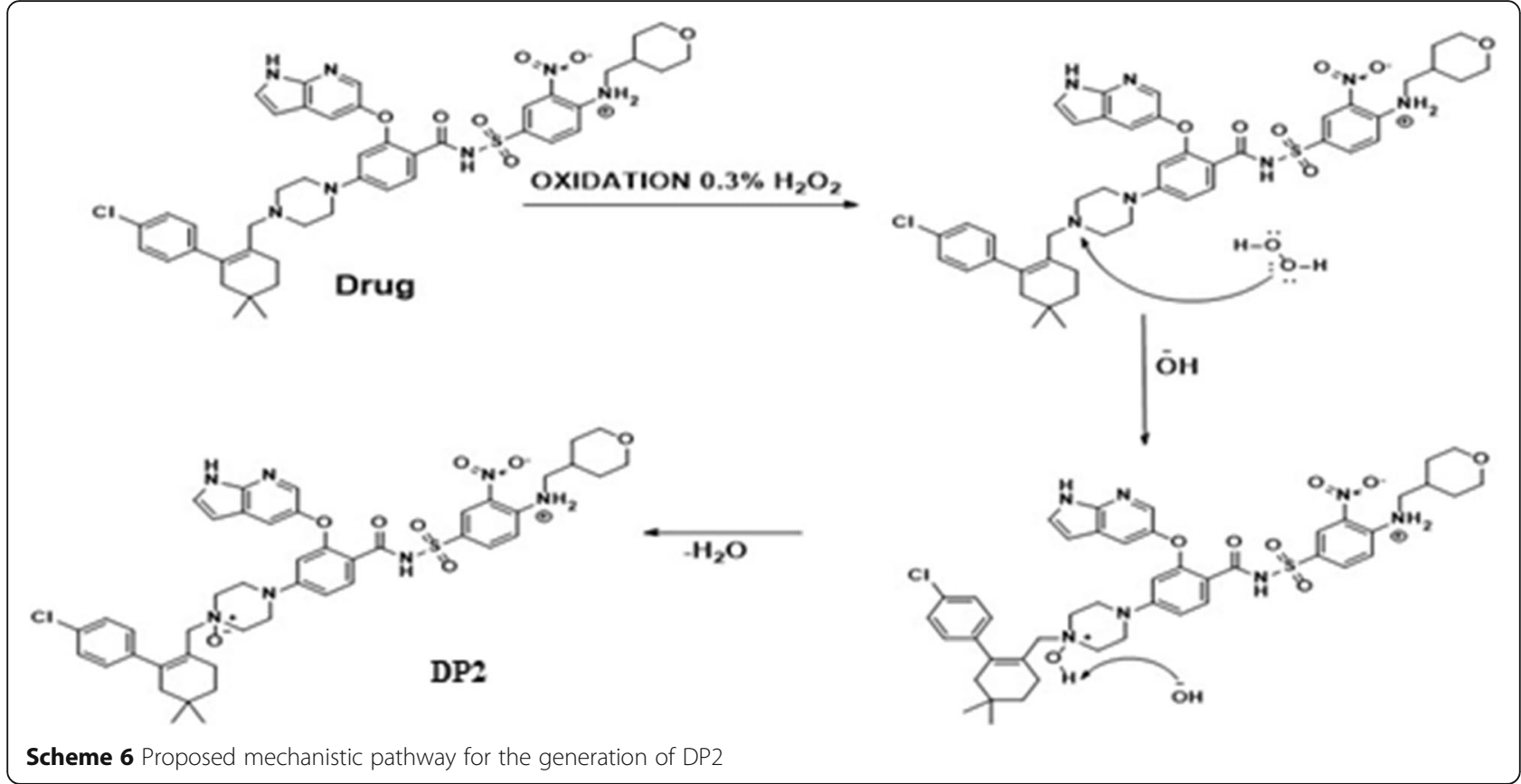

\section{MS/MS profiling of DP3}

MS/MS spectrum of DP3 formed in oxidative degradation (Figure 3d) showed protonated molecular ion at $\mathrm{m} / \mathrm{z}$ value of $527.2566\left(\mathrm{C}_{32} \mathrm{H}_{36} \mathrm{ClN}_{4} \mathrm{O}^{+}\right)$in positive ion mode. The fragmentation pattern of DP 3 is shown in Scheme 4 with major product ions at $\mathrm{m} / \mathrm{z} 295,233,191,177,163,83$, and 69. The elemental compositions of DP3 and its product ions was confirmed by accurate mass measurements (Table 2). DP3 was identified as 5-(3-(4-((4'-chloro-5,5-dimethyl-3,4,5,6-tetrahydro-[1,1'-biphenyl]-2-yl)methyl)piperazin-1-yl)phenoxy)-1H-pyrrolo[2,3-b]pyridine.

\section{A plausible mechanism of formation of DPs}

VEN was degraded into three degradation products in forced degradation experiments. DP1 was formed under acidic hydrolysis by cleavage of an amide bond and further formation of acid. DP2 was formed under oxidative conditions where oxygen was added to nitrogen of a piperazine ring leading to $\mathrm{N}$-oxide formation. DP3 was formed by oxidative decarboxylation under oxidative conditions, where there is a loss of carbon dioxide. The detailed mechanism is shown in Scheme 5, 6 and 7.

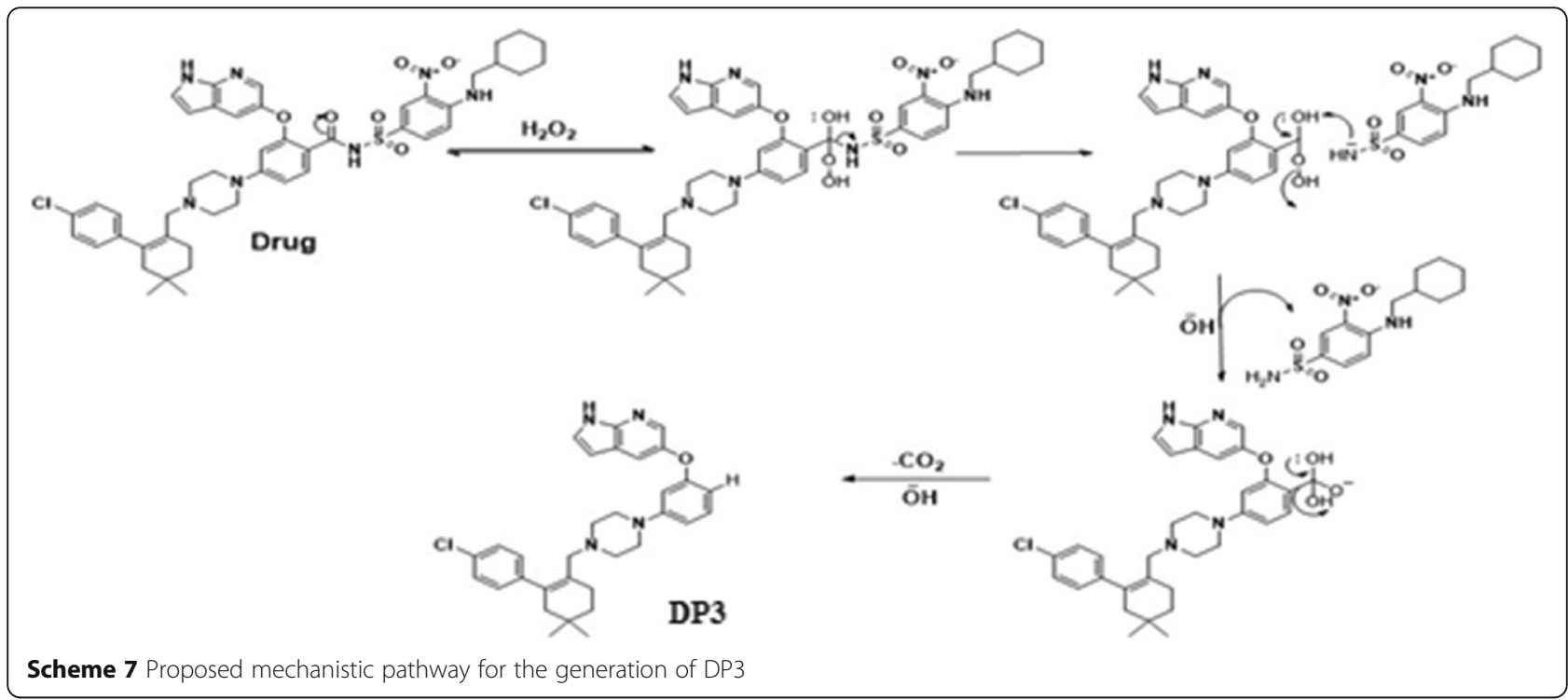


Table 3 System suitability study results

\begin{tabular}{lllll}
\hline System suitability (at $\mathbf{1 0 0} \%$ level ) & & \\
\hline Injections & Area & Asymmetry & $\begin{array}{l}\text { Retention } \\
\text { time }\end{array}$ & $\begin{array}{l}\text { Theoretical } \\
\text { plates }\end{array}$ \\
\hline S1 & 16226464 & 0.96 & 22.36 & 73017 \\
S2 & 15899107 & 0.95 & 22.44 & 72460 \\
S3 & 16026113 & 0.97 & 22.48 & 72671 \\
S4 & 15910984 & 0.95 & 22.44 & 73197 \\
S5 & 16152639 & 0.98 & 22.38 & 73072 \\
S6 & 16208396 & 0.96 & 22.34 & 73785 \\
Average & 16070617.17 & 0.96 & 22.41 & 73033.67 \\
SD & 146203.92 & 0.01 & 0.05 & 459.03 \\
\% RSD & $0.91 \%$ & $1.22 \%$ & $0.24 \%$ & $0.63 \%$ \\
\hline
\end{tabular}

\section{Method validation of VEN}

The HPLC method for VEN was validated following ICH Q2 (R2) guideline (ICH 2005). System suitability was determined by injecting a standard solution $(n=6)$ of VEN. Different parameters like retention time, area, asymmetry and theoretical plates were recorded and percent relative standard deviation (RSD) was calculated which was found to be less than 2 (Table 3). The standard linearity plot of peak area (y-axis) versus concentration ( $\mathrm{x}$-axis) was plotted by taking seven different concentrations in a range of 50 to $600 \mu \mathrm{g} / \mathrm{mL}$ in triplicate $(n=3)$. Correlation coefficient $\left(r^{2}\right)$ was determined through the linear regression equation and was found to be 0.9997 . The method accuracy was determined by spiking VEN in an excipient mixture at three different concentration levels of 320,400, and $480 \mu \mathrm{g} / \mathrm{mL}$ in triplicate (Khan et al. 2020). From the excipient mixture, VEN was extracted, filtered and analyzed. Percentage accuracy was between 99 to $101 \%$ at all three concentration levels (Table 4). The method precision was determined by injecting standard concentration for both within $(n=6)$ and between batch $(n=12)$ precision. The \%RSD of back-calculated concentration of the standard injections was less than 2 for all the experiments (Tables 5 and 6).

Table 4 Results of accuracy study

\begin{tabular}{lllll}
\hline $\begin{array}{l}\text { Nominal } \\
\text { Concentration } \\
(\boldsymbol{\mu g} / \mathbf{m L})\end{array}$ & $\begin{array}{l}\text { Average concentration } \\
\text { found }(\mathbf{n}=\mathbf{3})(\boldsymbol{\mu g} / \mathbf{m L})\end{array}$ & SD & RSD (\%) & $\begin{array}{l}\text { Mean } \\
\text { accuracy } \\
(\%)\end{array}$ \\
\hline $320(80 \%)$ & 322.69 & 0.77 & 0.23 & $100.84 \%$ \\
$400(100 \%)$ & 399.72 & 1.05 & 0.26 & $99.93 \%$ \\
$480(120 \%)$ & 478.78 & 2.36 & 0.49 & $99.74 \%$ \\
\hline
\end{tabular}

Table 5 Results of within batch precision study

\begin{tabular}{ll}
\hline Injections & Concentration $(\boldsymbol{\mu g} / \mathbf{m L})$ \\
\hline 1 & 392.00 \\
2 & 404.40 \\
3 & 404.92 \\
4 & 406.25 \\
5 & 407.66 \\
6 & 409.12 \\
Average & 404.22 \\
SD & 5.76 \\
RSD (\%) & 1.4 \\
\hline
\end{tabular}

\section{Conclusion}

In this study, a quantitative HPLC assay method has been established for quantification of VEN in presence of their degradation impurities. Stress study of VEN was performed by using different $\mathrm{ICH}$ recommended stresses including hydrolysis, oxidation, thermolysis and photolysis. We found three degradation products generated due to acidic hydrolysis and oxidative degradation. DP1 was formed in acidic hydrolysis whereas, DP2 and DP3 were formed in oxidative degradation. VEN was not degraded in basic hydrolysis, neutral hydrolysis, thermal and photolytic stress conditions. DP1, DP2 and DP3 were characterized by LC-Q-TOF-MS and their structures have been proposed based on their accurate mass data. Fragmentation patterns and plausible mechanism of formation of all three DPs have been proposed. This developed stability indicative method can be used in the routine analysis of quality control and stability samples in industry or other research laboratories.

Table 6 Results of between batch precision study

\begin{tabular}{ll}
\hline Injections & Concentration $(\boldsymbol{\mu g} / \mathbf{m L})$ \\
\hline 1 & 407.03 \\
2 & 409.06 \\
3 & 406.43 \\
4 & 410.29 \\
5 & 409.74 \\
6 & 404.14 \\
7 & 404.33 \\
8 & 415.67 \\
9 & 408.50 \\
10 & 406.52 \\
11 & 403.64 \\
12 & 408.15 \\
Average & 407.79 \\
SD & 3.31 \\
RSD (\%) & 0.81 \\
\hline
\end{tabular}




\section{Abbreviations}

VEN: Venetoclax; Bcl-2: B-cell lymphoma 2; USFDA: United States Food and Drug Administration; ICH: International Council for Harmonisation of Technical Requirements for Pharmaceuticals for Human Use; HPLC: High performance liquid chromatography; LC-MS: Liquid chromatography-mass spectrometry; Q-TOF: Quadrupole-time of flight; ACN: Acetonitrile; $\mathrm{NaOH}$ : Sodium hydroxide; $\mathrm{HCl}$ : Hydrochloric acid; DPs: Degradation products; $\mathrm{H}_{2} \mathrm{O}_{2}$ : Hydrogen peroxide; UV: Ultraviolet; RSD: Relative standard deviation; $r^{2}$ : Correlation coefficient

\section{Acknowledgements}

We are thankful to NIPER-Ahmedabad and Department of Pharmaceuticals, Ministry of Chemicals and Fertilizers, Govt. of India for providing the necessary facilities and support.

\section{Authors' contributions}

Dhruvisha Pokar: Data curation, Formal analysis, Investigation, Methodology, Validation, Visualization, Writing - original draft. Amit Kumar Sahu: Data curation, Formal analysis, Investigation, Methodology, Validation, Visualization, Writing - review \& editing. Pinaki Sengupta: Conceptualization, Investigation, Project administration, Supervision, Visualization, Writing - review \& editing. The authors read and approved the final manuscript.

\section{Funding}

Not applicable

Availability of data and materials

Not applicable

\section{Competing interests}

Not applicable

Received: 5 October 2020 Accepted: 2 December 2020

Published online: 11 December 2020

\section{References}

Alsante KM, Ando A, Brown R, Ensing J, Hatajik TD, Kong W, et al. The role of Degradant profiling in active pharmaceutical ingredients and drug products. Adv Drug Deliv Rev. 2007;59(1):29-37.

Bajaj S, Singla D, Sakhuja N. Stability testing of pharmaceutical products. J App Pharm Sci. 2012;2:129-38.

Bhavsar KA, Thakor DD, Thakor JR. A review article - development of forced degradation and stability indicating studies for drug substance and drug product. Int J Res Pharmacol Pharmacother. 2016;5:291-7.

Blessy M, Patel RD, Prajapati PN, Agrawal YK. Development of forced degradation and stability indicating studies of drugs - a review. J Pharm Anal. 2014;4:15965.

Brümmer D. How to approach a forced degradation study. Life Sci. 2011:31:1-4.

Chang Q, Yun S, Yang Y, Han Y, Renqi W. Chromatographic retention assisted Deconvolution of liquid chromatography-mass spectrometry chromatogram of natural products. Analytical sciences. Anal Sci. 2018;18:365.

Gousuddin M, Sengupta P, Chatterjee B, Das SK. Stability indicating RP-HPLC method for simultaneous quantitation of tramadol and aceclofenac in presence of their major degradation products: method development and validation. J Liq Chrom Rel Tech. 2017:40:887-93.

Hotha KK, Reddy SPK, Raju VK, Ravindranath LK. Forced degradation studies: practical approach - overview of regulatory guidance and literature for the drug products and drug substances. Int Res JPharm. 2013:4:78-85.

$\mathrm{ICH}$. Guidance for industry of new drug substances and products guidance for industry Q1A (R2) stability testing of new drug substances and products; 2003.

$\mathrm{ICH}$. Validation of analytical procedures: text and methodology Q2 (R1). Geneva: International Conference on Harmonization; 2005. p. 1-14.

Inturi S, Yejerla RK, Jujjuru NS, Avula PR. Evaluation of deuterium-labeled internal standard for the measurement of Venetoclax by HPLC-ESI -tandem mass spectrometry. J Young Pharm. 2018;10:392-8.

Jain S, Jadav T, Sahu AK, Kalia K, Sengupta P. An exploration of advancement in analytical methodology for quantification of anticancer drugs in biomatrices. Anal Sci. 2019;35:719-32.
Khan MN, Ali W, Shah Z, Idrees M, GULAB H. A validated Spectrofluorimetric method for the determination of Moxifloxacin in its pure form, pharmaceutical preparations, and biological samples. Anal Sci. 2020;36:361-6. Kitagawa S. Liquid chromatography. Anal Sci. 2019;35(9):949.

Liu H, Michmerhuizen MJ, Lao Y, Wan K, Salem AH, Sawicki J, et al. Metabolism and disposition of a novel B-cell Lymphoma-2 inhibitor Venetoclax in humans and characterization of its unusual metabolites. Drug Metab Dispos. 2017:45:294-305.

Mato AR, Thompson M, Allan JN, Brander DM, Pagel JM, Ujjani CS, et al. Real world outcomes and management strategies for venetoclax-treated chronic lymphocytic leukemia patients in the United States. Hematol J. 2018;103: 1511-7.

Roberts AW, Davids MS, Pagel JM, Kahl BS, Puvvada SD, Gerecitano JF, et al. Targeting BCL2 with Venetoclax in relapsed chronic lymphocytic leukemia. N Engl J Med. 2016;374:311-22.

Sahu AK, Sengupta P. Time of flight mass spectrometry based in vitro and in vivo metabolite profiling of ribociclib and their toxicity prediction. J Chromatogr B. 2020;1147:122142.

Sengupta P, Chatterjee B, Tekade RK. Current regulatory requirements and practical approaches for stability analysis of pharmaceutical products: a comprehensive review. Int J Pharm. 2018;543:328-44.

Sharma MK, Dhakne P, Sidhartha NN, Reddy PA, Sengupta P. Paradigm shift in the arena of sample preparation and bioanalytical approaches involving liquid chromatography mass spectroscopic technique. Anal Sci. 2019;35: 1069-82.

Sharma MK, Shah RP, Sengupta P. Amalgamation of stress degradation and metabolite profiling in rat urine and feces for characterization of oxidative metabolites of Flibanserin using UHPLCQ-TOF-MS/MS, H/D exchange and NMR technique. J Chromatogr B. 2020;1139:121993.

Watkins PJ. Characterization of four alkyl-branched fatty acids as methyl, ethyl, propyl, and butyl esters using gas chromatography-Quadrupole time of flight mass spectrometry. Anal Sci. 2020;36:425-9.

Žigart N, Časar Z. A literature review of the patent publications on venetoclax - a selective $\mathrm{BCl}-2$ inhibitor: discovering the therapeutic potential of a novel chemotherapeutic agent. Expert Opin Ther Pat. 2019;29:487-96.

\section{Publisher's Note}

Springer Nature remains neutral with regard to jurisdictional claims in published maps and institutional affiliations.

\section{Submit your manuscript to a SpringerOpen ${ }^{\circ}$ journal and benefit from:}

- Convenient online submission

- Rigorous peer review

- Open access: articles freely available online

- High visibility within the field

- Retaining the copyright to your article

Submit your next manuscript at $\boldsymbol{\nabla}$ springeropen.com 